\title{
KDM7A wt Allele
}

National Cancer Institute

\section{Source}

National Cancer Institute. KDM7A wt Allele. NCI Thesaurus. Code C158441.

Human KDM7A wild-type allele is located in the vicinity of $7 q 34$ and is approximately 92 $\mathrm{kb}$ in length. This allele, which encodes lysine-specific demethylase 7A protein, plays a role in brain development and histone modification. 